\title{
ResearchArticle
}

\section{Morpho-physiological evaluation of wheat variety AKAW-4627 under different irrigation schedules}

\author{
- JAYA TUMDAM, D.V. DURGE, N.R. POTDUKHE, MITALI DEOGIRKAR AND M.M. DESHMUKH
}

\section{SUMMARY}

Field experiment on morpho-physiological evaluation of wheat variety AKAW-4627 grown under different irrigation schedules was conducted during Rabi 2012-13 and 2013-14 at Wheat Research Unit, Dr. Panjabrao Deshmukh Krishi Vidyapeeth, Akola. An experiment was conducted in Randomized Block Design with four replications and net plot size of $7.2 \mathrm{~m}^{2}$. Different irrigation schedules on the basis of climatological approach i.e., on IW/CPE ratio; was utilized for irrigating the crop. Favourable soil moisture was maintained in the irrigation scheduling treatments of $1.2 \mathrm{IW} / \mathrm{CPE}$ and 1.0 IW/CPE throughout the growing period and it was always maintained in allowable depletion regime. The result indicated that the different irrigation schedules affected morpho-physiological attributes. It is concluded that 1.2 IW/CPE was found superior over rest of the treatments for morpho-physiological attributes followed by 1.0 IW/CPE, control, 0.8 IW/ $\mathrm{CPE}, 0.6 \mathrm{IW} / \mathrm{CPE}$ and no irrigation treatments. In respect of plant height $1.0 \mathrm{IW} / \mathrm{CPE}$ and control treatments were at par with each other.

Key Words : Irrigation scheduling, IW/CPE ratio

How to cite this article : Tumdam, Jaya, Durge, D.V., Potdukhe, N.R., Deogirkar, Mitali and Deshmukh, M.M. (2016). Morphophysiological evaluation of wheat variety AKAW-4627 under different irrigation schedules. Internat. J. Plant Sci., 11 (2): $203-206$, DOI: 10.15740/HAS/IJPS/11.2/203-206.

Article chronicle : Received : 22.01.2016; Revised : 10.04.2016; Accepted : 24.05.2016

\section{MEMBERS OF THE RESEARCH FORUM}

\section{Author to be contacted :}

JAYA TUMDAM, Department of Agricultural Botany, Post Graduate Institute, Dr. Panjabrao Deshmukh Krishi Vidyapeeth, AKOLA (M.S.) INDIA

\section{Address of the Co-authors:}

D.V. DURGE, N.R. POTDUKHE, MITALI DEOGIRKAR AND M.M. DESHMUKH, Department of Agricultural Botany, Post Graduate Institute, Dr. Panjabrao Deshmukh Krishi Vidyapeeth, AKOLA (M.S.) INDIA 